\title{
TELAAH UNDANG-UNDANG NOMOR 6 TAHUN 2014 TENTANG DESA DALAM MEWUJUDKAN KEDAULATAN PEMERINTAHAN DESA (STUDI KRITIS IMPLEMENTASI KEBIJAKAN NAWA CITA)
}

\author{
Kasmi’an, Subarkah dan Sukresno \\ Email : kasmian08@yahoo.co.id,subarkah_sh@yahoo.com, sukresno@umk.ac.id \\ Fakultas Hukum Universitas Muria Kudus
}

\begin{abstract}
ABSTRAK
Penelitian ini ingin membahas dan menelaah Undang-Undang Nomor 6 Tahun 2014 tentang Desa yang terkait dengan penerapan nawa cita, khususnya kedaulatan desa dari nawa cita presiden Jokowi-JK. Kedaulatan desa ini erat kaitannya dengan kewenangan atau wewenang yang dimiliki desa. Kewenangan atau wewenang adalah suatu istilah yang biasa digunakan dalam lapangan hukum publik. Adanya kewenangan desa dan belum adanya kejelasan peruntukan dana desa dalam pembagian dana sertastrategi target dan indikator Pembangunan Nasional Indonesia 2014-2019 berdasarkan Visi Misi Presiden Joko Widodo melalui Nawa Cita. Penelitian ini akan membahas tiga permasalahan yaitu apakah UU No. 6 Tahun 2014 tentang Desa berpeluang menciptakan kedaulatan dalam pemerintahan desa, sejauhmana pelaksanaan UU No. 6 Tahun 2014 tentang Desa melalui implementasi kebijakan Nawa Cita Pemerintahan Jokowi, dan problematika yang timbul beserta alternatif penyelesaiannya. Pendekatan yang digunakan dalam penelitian ini dalah yuridis empiris yang mengandung arti pendekatan yang menganalisis hukum bukan sebagai suatu peraturan perundang-undangan yang bersifat normatif saja, tetapi hukum dilihat sebagai gejala perilaku dan pola masyarakat dalam kehidupan, selalu berinteraksi dan berhubungan dengan aspek kemasyarakatan seperti politik, ekonomi, sosial dan budaya. Data primer diperoleh melalui observasi, wawancara dan kuesioner, sedangkan data sekunder dengan interpretasi perundang-undangan.
\end{abstract}

Kata Kunci : Desa, Kedaulatan Pemerintah Desa, Nawa Cita 


\section{PENDAHULUAN}

Pemerintahan desa menjadi garda terdepan dalam upaya mewujudkan kesejahteraan dan kemakmuran rakyat. Sebab, desa pada hakikatnya adalah entitas bangsa yang membentuk Negara Kesatuan Republik Indonesia. ${ }^{50}$

Masyarakat desa sangat bergantung terhadap program dan kegiatan pembangunan yang dijalankan, namun program yang berjalan selama ini masih terkesan apa adanya. Ketimpangan sosial dan kesenjangan ekonomi masih terjadi di desa.

Untuk itu, dibutuhkan peran pemerintah desa untuk mewujudkan kesejahteraan dan kemakmuran sesuai pembukaan Undang-Undang Dasar Negara Republik Indonesia Tahun 1945 alenia ke-empat. Kedaulatan pemerintah desa telah dikembalikan dengan lahirnya Undang-Undang Nomor 6 Tahun 2014 tentang Desa. UndangUndang ini diharapkan mengangkat hak dan kedaulatan desa. Dalam menjalankan Undang-Undang tersebut, di era pemerintahan Joko Widodo (Jokowi) dan Jusuf Kalla (JK) menetapkan visi-misi dengan Nawa Cita. Di poin ketiga, "Membangun Indonesia dari pinggiran dengan memperkuat daerah dan desa dalam kerangka negara kesatuan". Indikator visi-misi ini menyejahterakan desa dengan mengalokasikan dana desa, di mana setiap desa rata-rata memperoleh Rp 1,4 miliar dalam bentuk program bantuan khusus dan menjadikan

\footnotetext{
50 M. Silahuddin, "Kewenangan Desa dan Regulasi Desa, Kementerian Desa, Pembangunan Daerah Tertinggal", Kemendes, Jakarta, 2015, hlm. 11
}

Perangkat Desa menjadi Pegawai Negeri Sipil (PNS) secara bertahap.

Pemerintah mengalokasikan Dana Desa. Pada akhir periode pemerintahan Susilo Bambang Yudhoyono (SBY) mengalokasikan Dana Desa sekitar Rp 9 triliun. Pada era Jokowi, terjadi peningkatan alokasi Dana Desa lebih dari Rp 11 triliun atau menjadi Rp 20,8 triliun pada Tahun 2015..$^{51}$ Dalam pembahasan APBN 2015 ini bila dihitung rata-rata berkisar Rp. 260 juta per desa. Pada Tahun 2016, alokasi Dana Desa naik lebih dari dua kali lipat periode sebelumnya, mencapai $\mathrm{Rp}$ 46,96 triliun. Sehingga rata-rata Dana Desa yang diserahkan ke pemerintahan desa berada di atas Rp 500 juta.

Kenaikan alokasi Dana Desa juga terjadi dalam Rancangan APBN 2017 menjadi sekitar Rp 60 triliun. Jumlah ini naik tiga kali lipat dibandingkan Tahun 2015 lalu, Rp 20,8 triliun. Meski begitu, jumlah kenaikan Rp 60 triliun ini lebih rendah dibandingkan roadmap Dana Desa 2015-2019 yang disusun Kementerian Keuangan. Alokasi Dana Desa yang direncanakan untuk 2017 sekitar Rp 81 triliun. $^{52}$ Adanya peningkatan pengalokasian dana desa setiap tahun itu merupakan janji pemerintah. Bahwa setiap tahun alokasinya akan ditingkatkan secara bertahap sampai Rp 1 miliar lebih per desa.

Dana untuk pembangunan desa ini disalurkan secara bertahap. Pencairan Dana Desa sesuai PMK Nomor

\footnotetext{
51 Gilang Muhammad, http://himiespa.feb. ugm.ac.id/desa-membangun-perubahanparadigma-pembangunan-desa/, diakses 29 Desember 2017 pukul 20.00 .

52 Maya Rostanty, http://kedesa.id/idID/ kenaikan-dana-desa-di-apbn-2017-danakuntabilitas-keuangan-desa/ diakses 28 Desember 2017 pukul 20.30.
} 
40/PMK.07/2016 menjadi dua tahapan, yaitu 60 persen dan 40 persen. Pencairan ini berkat adanya sinergi Kementerian Desa PDTT dan Kementerian Keuangan. Pemerintah desa telah diberi panduan atau pedoman tentang penggunaan Dana Desa.

Dana Desa tersebut diprioritaskan untuk pembiayaan pembangunan dan pemberdayaan masyarakat, yang pelaksanaannya dilakukan secara swakelola. Pembangunannya juga menggunakan sumber daya atau bahan baku lokal dan diupayakan lebih banyak menyerap tenaga kerja dari masyarakat desa setempat.

Penggunaan Dana Desa juga berdasarkan aspek keadilan dengan mengutamakan hak atau kepentingan seluruh warga desa tanpa membedabedakan, aspek prioritas dengan mendahulukan kepentingan desa yang lebih mendesak, lebih dibutuhkan dan berhubungan langsung dengan kepentingan sebagian besar masyarakat, dan aspek tipologi desa dengan mempertimbangkan keadaan dan kenyataan karakteristik geografis, sosiologis, antropologis, ekonomi, dan ekologi desa yang khas, serta perubahan atau perkembangan kemajuan desa. ${ }^{53}$

Dana Desa ini untuk mengangkat harkat, martabat, kesejahteraan dan kemakmuran hidup masyarakat pinggiran. Harapannya tidak ada lagi jurang pemisah antara wilayah perkotaan dengan pedesaan. Pemerintahan desa didorong untuk mandiri karena pembangunan menjadi tanggung jawab desa sendiri.

Berdasarkan latar belakang di atas, ada beberapa perumusan permasalahan yang akan dibahas yaitu :

53 Lihat: Permendes Nomor 22 Tahun 2016, Bab 2 Pasal 3.
1) Apakah Undang-Undang Nomor 6 Tahun 2014 tentang Desa berpeluang menciptakan kedaulatan dalam pemerintahan desa sebagaimana dicita-citakan?

2) Sejauhmana pelaksanaan UndangUndang Nomor 6 Tahun 2014 tentang Desa melalui implementasi kebijakan Nawa Cita pemerintahan Jokowi-Jusuf Kalla?

3) Bagaimana problematika yang timbul dan alternatif penyelesaiannya?

\section{METODE PENELITIAN}

Metode pendekatan yang dipakai yaitu pendekatan yuridis empiris, khususnya implementasi program Nawa Cita di wilayah pedesaan di Kabupaten Kudus. Pendekatan yuridis empiris mengandung arti pendekatan yang menganalisis hukum bukan sematamata sebagai suatu perangkat peraturan perundang-undangan yang bersifat normatif saja, tetapi hukum dilihat sebagai gejala perilaku dan pola kehidupan masyarakat.

Penelitian ini menggunakan metode deskriptif analitis, yaitu mendeskripsikan realitas yang ada dalam usaha untuk pemecahaan masalah berdasarkan teori hukum yang ada.

Perolehan data menggunakan data primer dan data sekunder. Data primer diperoleh melalui wawancara yang melibatkan responden dari kepala desa, ketua BPD, perangkat desa dan pejabat di Dinas Pemberdayaan Masyarakat Desa dan Bagian Pemerintahan Desa Sekretariat Daerah Kudus. Sedangkan data sekunder diperoleh dari studi kepustakaan. 
HASIL PENELITIAN DAN

PEMBAHASAN

\section{Peluang Undang-Undang Desa dalam Menciptakan Kedaulatan Desa}

Gagasan untuk melahirkan suatu undang-undang khusus tentang Desa sebenarnya sudah berkali-kali muncul. Lahirnya Undang-undang Nomor 6 Tahun 2014 ditengarai oleh beberapa persoalan yang terjadi baik dari segi peraturan perundangan sebelumnya maupun dari segi persoalan pemberdayaan desa serta perkembangan zaman yang harus dihadapi. Undang-undang desa tersebut dinilai mulai mengangkat hak dan kedaulatan desa yang selama ini terpinggirkan.

Melihat tujuan undang-undang tersebut, kedaulatan desa lebih diperhatikan. Menurut Nurul Mustain, Kepala Desa Piji Kecamatan Dawe, keberadaan Undang-Undang Nomor 6 Tahun 2014 sangat membantu dalam penyelenggaraan pemerintah desa, khususnya dalam hal pedoman penyelenggaraan pemerintah desa. ${ }^{54}$ Nada yang hampir sama dikemukakan Noor Chamid, Kepala Desa Purworejo, terciptanya landasan yang kuat dalam penyelenggaraan pemerintahan desa. ${ }^{55}$ Tujuannya supaya pembangunan masyarakat yang demokratis, adil, makmur dan sejahtera. Regulasi tersebut mendudukkan desa dan masyarakat sebagai subyek pembangunan desa. Dalam perencanaan dan pelaksanaan pembangunan desa, peran serta dan

54 Ibid.

55 Noor Chamid, “Angket Riset Penelitian”, Kepala Desa Purworejo, 12 Januari 2018, Purworejo, Bae, Kudus pelibatan masyarakat dibutuhkan dalam membangun desa.

Nada positif dikemukakan pula oleh Munaji, Kepala Desa Peganjaran Kecamatan Bae, dimana UndangUndang Nomor 6 Tahun 2014 adalah regulasi yang mengatur tentang desa. ${ }^{56}$ Dalam kandungan peraturan ini, desa diberikan kewenangan tersendiri untuk mengatur dan membangun desa dengan dialokasikannya Dana Desa (DD). Badrus, Kepala Desa Getassrabi Kecamatan Gebog menilai, bahwa melalui undang - undang ini, desa diberi hak kewenangan untuk menata desanya sendiri (otonomi desa). Melalui undang-undang ini pembangunan lebih terarah dan terukur, dan desa menjadi kuat, karena diberikan hak kemandirian desa. ${ }^{57}$

Pendapat mengenai hal ini dikemukakan pula oleh Arief Budi Siswanto, Sekretaris Dinas Pemberdayaan Masyarakat Desa Kabupaten Kudus yang berpendapat, bahwa Undang-Undang Nomor 6 Tahun 2014 merupakan pedoman penyelenggaraan pemerintah desa, artinya desa mempunyai pegangan dalam mengatur dan mengurus urusan pemerintahan, kepentingan masyarakat setempat berdasarkan prakarsa masyarakat, hak asal-usul dan tidak melupakan azas dan landasan yang ada dan berlaku. ${ }^{58}$

Melihat beberapa pendapat mengenai sisi kelebihan sistem pemerintahan sejak lahirnya Undang-

56 Munaji, “Angket Riset Penelitian”, Kepala Desa Peganjaran, 5 Februari 2018, Peganjaran, Bae, Kudus

57 Badrus, “Angket Riset Penelitian”, Kepala Getassrabi, Gebog, 20 Februari 2018, Getassrabi, Gebog, Kudus.

58 Arief Budi Siswanto, "Angket Riset Penelitian”, Sekretaris Dinas PMD Kab. Kudus, 22 Februari 2018, Kudus. 
Undang Nomor 6 Tahun 2014, desa pada dasarnya memiliki peluang besar untuk mewujudkan kemandirian dan tata kelola penyelenggaraan pemerintahan desa secara maksimal. Namun harus diimbangi dengan berbagai terobosan sehingga desa dapat mendongkrak potensi dan aset yang dimiliki desa yang akan dijadikan sebagai embrio berdirinya Badan Usaha Milik Desa (BUMDesa) yang bisa menjadi sumber pemasukan Pendapatan Asli Desa (PAD) untuk peningkatan kesejahteraan masyarakat desa.

Terkait dengan pengembangan BUMDesa tersebut, hal senada dikemukakan pula oleh Munaji, Kepala Desa Peganjaran Kecamatan Bae, bahwa perlu memaksimalkan pemanfaatan dan pendayagunaan potensi yang dimiliki desa. ${ }^{59}$ Hal ini ditempuh dengan jalan mengeksploitasi seluruh kemampuan atas potensi sumber daya manusia, penggalian sektor-sektor perekonomian desa serta pendirian BUMDesa, Desa Mart dan peningkatan layanan masyarakat sesuai tupoksi dan kewenangan yang dimiliki. ${ }^{60}$

Badrus, Kepala Desa Getasrabi Kecamatan Gebog, terhadap masalah ini berpedapat melalui memajukan desa dengan menggunakan inovasiinovasi baru, mengumpulkan sarjana desa setempat (masyarakat lokal desa) untuk diajak musyawarah dalam memajukan desanya, memaksimalkan

\footnotetext{
59 Munaji, “Angket Riset Penelitian”, Kepala Desa Peganjaran, 5 Februari 2018, Peganjaran, Bae, Kudus.

60 Munaji, “Angket Riset Penelitian”, Kepala Desa Peganjaran, 5 Februari 2018, Peganjaran, Bae, Kudus.
}

keterlibatan masyarakat secara umum dalam hal perencanaan, pelaksanaan, pengawasan dan pelestarian kegiatan pembangunan desa, berusaha memaksimalkan skill bagi perangkat desa dengan berbagai wahana pembelajaran, baik formal maupun non formal, dan pengembanagan atau pendirian Badan Usaha Milik Desa (BUMDesa).

Arif Hidayatullah, Anggota BPD Desa Kuwukan Kecamatan Dawe, berpendapat, bahwa untuk mencapai kemandirian dan tata kelola penyelenggaraan pemerintah desa, maka desa dapat menggali potensi kemampuan ekonomi masyarakat, misalnya membentuk BUMDesa yang dapat mengelola berbagai produk lokal dan pengolahan hasil pertanian. ${ }^{61} \mathrm{Di}$ samping itu adalah melalui meningkatkan infrastruktur pembangunan seperti jalan desa, jalan lingkungan, jalan usaha tani dan sarana infra struktur lainnya.

Arief Budi Siswanto, Sekretaris pada Dinas PMD Kabupaten Kudus, berpendapat, untuk mencapai kemandirian dan tata kelola penyelenggaraan pemerintah desa, desa harus berpegang teguh pada azas dalam peraturan pemerintahan desa, diantaranya mengotimalkan gotong royong, demokrasi, musyawarah, kebersamaan, partisipasi dan kemandirian. ${ }^{62}$

\footnotetext{
61 Arif Hidayatullah, Angket Riset Penelitian", Wakil Ketua BPD Desa Kuwukan, 17 Februari 2018, Kuwukan, Dawe, Kudus.

62 Arief Budi Siswanto, "Angket Riset Penelitian”, Sekretaris Dinas PMD Kab. Kudus, 22 Februari 2018, Kudus.
} 


\section{Implementasi Kebijakan Nawa} Cita

Nawa Cita Jokowi dan Yusuf Kalla, poin yang berhubungan langsung dengan kebijakan UndangUndang Nomor 6 Tahun 2014 tentang Desa adalah poin ketiga yang berbunyi : "Kami akan membangun Indonesia dari pinggiran dengan memperkuat Daerah-daerah dan Desa dalam kerangka Negara Kesatuan.” Berdasarkan target dan indikator Pembangunan Nasional Indonesia 2014-2019 nampak pembangunan daerah/desa bukan berarti pembangunan secara fisik belaka. Poin lanjutan Nawa Cita tentang visi "berdaulat secara politik."

Merujuk Peraturan Menteri Desa, Pembangunan Daerah Tertinggal dan Transmigrasi Nomor 19 Tahun 2017 tentang Prioritas Penggunaan Dana Desa tahun 2018, pemerintah secara lebih detail mengatur bagaimana dana desa akan digunakan. Dalam peraturan tersebut, prioritas dana desa dibagi menjadi dua bidang, yaitu bidang pembangunan desa dan bidang pemberdayaan masyarakat desa.

Dari hasil analisis jawaban responden terkait peranan Dana Desa (DD) dalam mendukung terwujudnya Program Nawa Cita Jokowi - JK, terutama Nawa Cita ketiga, sebagian besar memberikan respon positif. Misalnya seperti yang dikemukakan oleh Nurul Mustain, Kepala Desa Piji Kecamatan Dawe berpendapat bahwa dengan adanya Dana Desa (DD) pelaksanaan pembangunan di setiap dukuhan dan lingkungan RT dan RW semakin hari semakin bertambah baik volume maupun titik lokasi kegiatan pelaksanaan pembangunannya. 63 Demikian pula sebagimana dikemukakan Noor Chamid, oleh Kepala Desa Purworejo, bahwa dengan keberadaan Dana Desa (DD), maka program Nawa Cita bisa terwujud. $^{64}$ Karena jika desa semakin maju dengan melakukan pembangunan di segala bidang, maka desa akan menjadi kuat. Desa mampu menjadi tolak ukur kekuatan dan kemakmuran sebuah negara. Arief Budi Siswanto, Sekretaris Dinas Pembangunan Masyarakat Desa (PMD) Kabupaten Kudus, merespon pula bahwa desadesa yang menjadi ujung tombak kesejahteraan ekonomi sosial negeri ini. Dengan melakukan pembangunan desa, akan memperkaya sumber daya manusia (SDM) sehingga mampu memperkuat ekonomi Negara Kesatuan Republik Indonesia. ${ }^{65}$

Hal senada dikemukakan oleh Mochamad Arifin, Kepala Desa Sidorekso, dimana keberadaan Dana Desa (DD) mampu untuk mewujudkan pemerataan pembangunan masyarakat desa dalam berbagai sektor, khususnya pemenuhan pelayanan masyarakat dalam pembangunan sarana dan prasarana infrastruktur desa. ${ }^{66}$ Demikian pula halnya Munaji, Kepala Desa Peganjaran Kecamatan Gebog, yang setuju bahwa peranan Dana Desa (DD) mampu untuk mendukung terwujudnya Program Nawa Cita

63 Nurul Mustain, "Angket Riset Penelitian", Kepala Desa Piji, 12 Maret 2018, Piji, Dawe, Kudus.

64 Noor Chamid, "Angket Riset Penelitian", Kepala Desa Purworejo, 12 Januari 2018, Purworejo, Bae, Kudus.

65 Arief Budi Siswanto, "Angket Riset Penelitian", Sekretaris Dinas PMD Kab. Kudus, 22 Februari 2018, Kudus.

66 Mochamad Arifin, "Angket Riset Penelitian", Kepala Desa Sidorekso, 16 Januari 2018, Sidorekso, kaliwungu, Kudus. 
Jokowi-JK, karena desa merupakan tumpuan utama penggerak roda pemerintahan di Negara Kesatuan Indonesia. $^{67}$ Jika desa itu kuat dan maju, maka Negara juga akan mengalami kekuatan dan kemajuan, sehingga stabilitas nasional tidak terganggu. Hanya sayangnya, demikian sisi kelemahan yang diungkapkan oleh Munadji, petunjuk penggunaan Dana Desa (DD) kurang fleksibel dan perlu penyempurnaan lebih lanjut.

Anggota Badan Permusyawaratan Desa Kuwukan, Arif Hidayatullah, merespon mengenai manfaat Dana Desa (DD) merupakan peluang baik bagi desa. ${ }^{68}$ Melalui Dana Desa (DD) itulah maka pertumbuhan dan perkembangan perekonomian desa dapat tumbuh dengan cepat. Selain itu, desa juga bisa mewujudkan kemandirian sebuah desa.

Meskipun secara umum Badrus, Kepala Desa Getassrabi, memberikan respon positif bahwa Dana Desa akan mampu dalam mewujudkan Nawa Cita tersebut, khusunya Nawa Cita ketiga, namun ada beberapa catatan yang perlu diperhatikan, yaitu menyangkut keberadaan kebijakan program Padat Karya Tunai yang belakangan ini muncul, namun di daerah-daerah belum sesuai kebutuhan. ${ }^{69}$ Program Padat Karya Tunai ini parameternya tidak jelas, bahkan terkesan menghambur-hamburkan uang rakyat (sing penting ono wonge). Kapasitas dan kemampuan pekerja program

67 Munaji, “Angket Riset Penelitian”, Kepala Desa Peganjaran, 5 Februari 2018, Peganjaran, Bae, Kudus.

68 Arif Hidayatullah, Angket Riset Penelitian", Wakil Ketua BPD Desa Kuwukan, 17 Februari 2018, Kuwukan, Dawe, Kudus.

69 Badrus, “Angket Riset Penelitian”, Kepala Getassrabi, Gebog, 20 Februari 2018, Getassrabi, Gebog, Kudus
Padat Karya Tunai di desa akan berdampak pada mutu dan hasil pekerjaannya. Out put dan hasil capaian pekerjaannya juga kurang mantap dan masih pula dilakukan penuntukan rekanan yang ahli. ${ }^{70}$

Bantuan Dana Desa pada prinsipnya sangat bermanfaat, namun demikian ada satu catatan penting dalam hal ini sebagaimana dikemukakan oleh Lexie M. Giroth, bahwa pemberdayaan sumber daya manusia bukan membuat masyarakat menjadi semakin tergantung pada berbagai progam pemberian, karena pada dasarnya setiap apa yang dinikmati harus dihasilkan usaha sendiri yang hasilnya dapat dipertukarkan dengan pihak lain. Dengan demikian, tujuan akhirnya adalah memandirikan, memampukan dan membangun kemampuan untuk memajukan diri kea rah kehidupan yang lebih baik secara seimbang. ${ }^{71}$ Akhirnya kondisi yang diharapkan adalah peraturan tersebut dapat diterjemahkan oleh pemerintah daerah, dari prioritas-prioritas yang ada tersebut, sesungguhnya prioritas manakah yang benar-benar menjadi prioritas.

3. Permasalahan dan Pemecahan Masalah dalam Menciptakan Kedaulatan Desa

Melaksanakan Undang-Undang Nomor 6 Tahun 2014 tentang Desa, Pemerintah Kabupaten Kudus membuat mengupayakan agar dana desa dapat dikelola dengan baik. Berbagai upaya juga dilakukan agar penyelewengan dana desa tidak terjadi. Di antaranya membuat Peraturan Bupati Kudus

70 Ibid.

71 Lexie M. Giroth, "Status Pendidikan Pramong Praja Indonesia," CV. Indra Prahasta, 2004, hlm. 38. 
Nomor 12 Tahun 2016 tentang Pengelolaan Dana Desa. Pemerintah Kabupaten Kudus pada November 2016 lalu berencana menerapkan sistem aplikasi keuangan desa.

Selain itu, menghindari kasus korupsi, Kejaksaan Negeri (Kejari) Kudus membentuk Tim Pengawal dan Pengamanan Pemerintah dan Pembangunan Daerah (TP4D). Tim itu akan mengawal implementasi dana desa. $^{72}$

Badrus, Kepala Desa Getassrabi yang berpendapat, mekanisme dan implementasi Dana Desa (DD) sudah bagus namun masih banyak ruang untuk dimanipulasi maupun mark up atas kegiatan yang dilaksanakan ${ }^{73}$. Kepala Desa Getasrabi ini juga menilai bahwa Tim Pelaksana Kegiatan (TPK) masih banyak yang tidak mampu melakukan tata laksana administrasi pembukuan sebuah kegiatan di wilayahnya masingmasing. Kelemahan lainnya yang juga dianggap fatal adalah menyangkut peran pendamping Desa (PD) yang tidak maksimal, sehingga tingkat pemberdayaan dan kemandirian masyarakat dalam melakukan tata kelola pekerjaan dan pelaksanaan kegiatan yang sumber dananya dari Dana Desa (DD) maupun sumber pendanaan lainnya tidak bisa maksimal.

Pada dasarnya permasalahan yang dihadapi penggunaan Dana Desa, belum sepenuhnya mampu memberdayakan masyarakat. Sebagaimana diungkapkan Nurul Mustain, Kepala Desa Piji Kecamatan Dawe, yang beranggapan bahwa kendala yang dihadapi

\footnotetext{
${ }^{72}$ https://www.jawapos.com/radarkudus/read/20 17/08/25/9665/implementasi-dana-desadikawal-kejari diakses pada 20 Oktober 2017

73 Badrus, “Angket Riset Penelitian”, Kepala Getassrabi, Gebog, 20 Februari 2018, Getassrabi, Gebog, Kudus.
}

pemerintah desa dalam pelaksanaan dan implementasi penggunaan Dana Desa masih dianggap kurang, bahkan tidak mendorong partisipasi masyarakat. ${ }^{74}$

Hal senada dikemukakan oleh Noor Chamid, Kepala Desa Purworejo Kecamatan Bae, bahwa dengan dana desa yang cukup banyak, menjadikan masyarakat justru enggan untuk berswadaya dan gotong royong ${ }^{75}$. Di sampimg itu masyarakat mulai enggan pula untuk diajak kerjasama dalam kebersihan lingkungan, jalan, selokan dan infrastruktur lainnya. Dengan perkataan lain keberadaan Dana Desa justru menimbulkan perspektif negatif, yaitu membunuh semangat kebersamaan masyarakat desa dalam kerja bhakti dan gotong royong.

Kendala implementasi Dana Desa di Kabupaten Kudus diungkapkan pula oleh Sekretaris Dinas Pemberdayaan Masyarakat Desa (PMD) Kabupaten Kudus, adalah menyangkut minimnya sumber daya manusia, dan kurangnya kesadaran masyarakat terhadap pentingnya pengawasan berbasis masyarakat. $^{76}$ Oleh karena itu, sebagaimana diungkapkan oleh Kepala Desa Sidorekso Kecamatan Kaliwungu, bahwa dalam upaya implementasi Undang-Undang Nomor 6 Tahun 2014, maka Sumber Daya Manusia (SDM) aparatur perangkat desa perlu untuk ditingkatkan dan diberdayakan ${ }^{77}$.

\footnotetext{
74 Nurul Mustain, “Angket Riset Penelitian”, Kepala Desa Piji, 12 Maret 2018, Piji, Dawe, Kudus.

75 Noor Chamid, “Angket Riset Penelitian”, Kepala Desa Purworejo, 12 Januari 2018, Purworejo, Bae, Kudus.

76 Arief Budi Siswanto, "Angket Riset Penelitian”, Sekretaris Dinas PMD Kab. Kudus, 22 Februari 2018, Kudus.

${ }^{77}$ Mochamad Arifin, “Angket Riset Penelitian”, Kepala Desa Sidorekso, 16 Januari 2018, Sidorekso, Kaliwungu, Kudus.
} 
Dampak dari permasalahan ini bisa mengarah pada realisasi penggunaan dana dan pertanggungjawabannya. Pada tahun anggaran 2017, dari alokasi dana desa di Kabupaten Kudus mencapai Rp 219,89 miliar. Jumlah ini berbeda pada tahun sebelumnya (2016), dana desa tahun ini lebih tinggi karena hanya $\mathrm{Rp}$ 194,832 miliar. $^{78}$ Hingga pada tahun, proses pencairan dana masih menyisakan kendala. Kepala Dinas Pemberdayaan Masyarakat dan Desa Kabupaten Kudus, Adi Sadhono Murwanto mengatakan pencairan dana itu masih menyisakan satu desa. ${ }^{79}$ Padahal memasuki bulan Agustus sudah masuk pencairan tahap kedua. Hal ini Berdasarkan Peraturan Bupati Kudus Nomor 15/2017 tentang Tata Cara Pembagian dan Penetapan Besaran Dana Desa di Kabupaten Kudus Tahun Anggaran 2017, dijelaskan penyaluran Dana Desa untuk tahap pertama dimulai Maret 2017 sebesar 60\%. Sementara penyaluran tahap kedua, dimulai Agustus 2017 dengan persentase $40 \%$.

Arif Hidayatullah, anggota Badan Permusyawaratan Desa (BPD) Desa Kuwukan, melihat kendala yang sering dihadapai diantaranya meliputi pemerintah desa seringkali kurang koordinasi dalam hal informasi terkait dengan pelaksanaan atau belanja desa yang berkaitan dengan APBDes yang di dalamnya juga tentang penggunaan Dana Desa (DD), pengawasan hanya melalui pengawasan administratif pada laporan pertanggungjawaban

\footnotetext{
${ }^{78} \mathrm{http}$ ://www.antaranews.com/berita/607511/alo kasi-dana-untuk-desa-di-kudus-capai rp21989-miliar diakses pada 18 Oktober 2017 pukul.

79 Adi Sadhono Murwanto, "Wawancara", Kepala Dinas Pemberdayaan Masyarakat dan Desa Kabupaten Kudus, 2 Maret 2018, Kudus.
}

penggunaan Dana Desa (DD) secara umum yang tidak dapat diketahui secara riil, seperti bukti-bukti transaksi belanja, sehingga tidak dapat nelakukan pengawasan secara optimal. ${ }^{80}$ Lemahnya fungsi pengawasan ini diungkapkan pula oleh anggota Badan Permusyawaratan Desa (BPD) Desa Lau, Abdul Rois, bahwa mekanisme pengawasan yang dilakukan kurang maksimal, karena pihak pemerintah desa selalu menutup-nutupi kekerangannya. ${ }^{81}$ Dengan perkataan lain pemerintah desa tidak mau melaksanakan mekanisme dan aturan main yang sebenarnya. Dalam memahami atas implementasi Dana Desa (DD) dalam keyataannya tidak ada kesinkronan antara perencanaan awal dengan kondisi pelaksanaan pekerjaan dilapangan ${ }^{82}$ Di samping itu keberadaan Pendamping Desa (PD) dan Pendamping Lokal Desa (PLD) tidak maksimal, mereka terkadang tidak memahami aturan mainnya.

Dampak dari lemahnya penggunaan anggaran desa tahun 2016, baik Alokasi Dana Desa (ADD) atau Dana Desa (DD) di Kabupaten Kudus tercatat ada kepala desa yang terjerat kasus korupsi dana desa, yaitu Kepala Desa Padurenan Kecamatan Gebog, Arif Chuzaimahtum, yang diduga melakukan korupsi dana desa anggaran 2015 yang totalnya mencapai Rp 432,88 juta. Kejaksaan Negeri Kudus telah menetapkan Kepala Desa Padurenan sebagai tersangka atas dugaan korupsi

80 Arif Hidayatullah, Angket Riset Penelitian", Wakil Ketua BPD Desa Kuwukan, 17 Februari 2018, Kuwukan, Dawe, Kudus.

81 Abdul Rois, “Angket Riset Penelitian", Ketua BPD Desa Lau, 18 Januari 2018, Lau, Dawe, Kudus.

82 Badrus, “Angket Riset Penelitian", Kepala Getassrabi, Gebog, 20 Februari 2018, Getassrabi, Gebog, Kudus 
dana kas desa maupun dana desa untuk Desa Padurenan sejak Februari 2016. ${ }^{83}$ Pada Febuari 2017 lalu, Kepada Desa Undaan juga sempat dilaporkan ke polisi karena dugaan penyelewengan dana desa. ${ }^{84}$ Meski belum terbukti dan tak ada kabar lanjutan kasus tersebut, administrasi transparasi anggaran yang kurang baik bisa jadi penyebabnya.

Kasus-kasus serupa mengenai proses pencairan dana desa banyak ditemui di berbagai desa yang lain di luar Kabupaten Kudus. Adapun kasus korupsi, berdasarkan laporan Indonesia Corruption Watch (ICW) ada 110 kasus penyelewengan dana desa dan alokasi dana desa sepanjang 2016-10 Agustus 2017. Dari 110 kasus itu, pelakunya rata-rata dilakukan kepala desa. ${ }^{85}$

\section{Kesimpulan}

1) Secara umum dengan lahirnya Undang-Undang Nomor 6 Tahun 2014 tentang Desa apabila dikaitkan kebijakan Nawa Cita poin ketiga, dana desa merupakan peluang baik bagi desa untuk mewujudkan program Nawa Cita, pertumbuhan perekonomian desa tumbuh dengan cepat, pemerintah desa mampu mewujudkan kemandirian desa yang kuat dan makmur.

2) Upaya mensejahterakan masyarakat desa dan mewujudkan pemerintah desa yang otonom melalui strategi mewujudkan kedaulatan desa sebagaimana diamanatkan UndangUndang Nomor 6 Tahun 2014 ,di

\footnotetext{
${ }^{83} \mathrm{http}: / /$ www.antarajateng.com/detail/kepaladesa-tersangka-korupsi-ditahan.html diakses pada 19 Januari 2018.

${ }^{84}$ http://www.rakyatmuria.com/2017/02/22/didu ga-selewengkan-dana-desa-kades-undaanlor-dilaporkan-ke-polisi/ diakses pada 19 Januari 2018.

${ }^{85}$ https://news.detik.com/berita/d-3596041/ icwsebut-pak-kades-paling-banyak-korupsidana-desa diakses pada 19 Januari 2018.
}

Kabupaten Kudus, belum sepenuhnya terlaksana dengan baik, karena banyak faktor yang menjadi kendala dalam mewujudkan hal dimaksud, diantaranya menyangkut sumber daya perangkat desa.

3) Problematika yang timbul dalam mewujudkan kedaulatan dalam pemerintahan desa, di antaranya partisipasi masyarakat pembangunan desa belum sepenuhnya berjalan sebagaimana yang diharapkan, dana desa untuk membiayai program pemberdayaan masyarakat desa belum sepenuhnya dapat menghidupi kondisi desa secara mandiri, belum jelasnya dan terpahaminya konsep tentang kedaulatan pemerintahan desa karena kepala desa masih menganggap bawahan camat atau bupati, pengangkatan Perangkat Desa sebagai Pegawai Negeri Sipil kurang relevan dan belum merupakan solusi terbaik terhadap upaya mewujudkan kedaulatan desa, dan masih ada program-program dari pusat yang bermasalah, khususnya pendamping desa.

Solusi yang perlu diambil terkait problematika ini adalah melakukan evaluasi terhadap program dengan harapan memberikan pencerahan terhadap permasalahan yang ada, memberikan pemahaman kepada pejabat, khususnya bupati dan camat, bahwa kepala desa bukanlah bawahan.

\section{Saran}

Berdasarkan kesimpulan hasil penelitian ini, maka secara khusus penulis menyampaikan saran kepada Pemerintah Daerah Kabupaten Kudus dan Pemerintah Desa untuk :
1. Mewujudkan
kesejahteraan
masyarakat desa dan mewujudkan 
pemerintah desa yang otonom perlu diupayakan, di antaranya melalui peningkatan sumber daya manusia perangkat desa.

2. Secara bertahap menghilangkan pola pikir dan stigma kepala desa adalah bawahan camat atau bupati.

3. Memaksimal kompetensi sumber daya manusia perangkat desa. Perubahan status sebagai PNS bukan jaminan perubahan kondisi.

4. Memaksimalkan dan mengevaluasi kebijakan pendamping desa sehingga keberadaan pendamping desa sesuai harapan.

5. Pemanfaatan dana desa secara maksimal sehingga mampu meningkatkan kapasitas dan kapabilitas masyarakat desa melalui pemberdayaan potensi dan sumber daya desa.

\section{DAFTAR PUSTAKA}

M. Silahuddin, "Kewenangan Desa dan Regulasi Desa, Kementerian Desa, Pembangunan Daerah Tertinggal", Kemendes, Jakarta, 2015.

Soerjono Soekanto, "Pengantar Penelitian Hukum”, Penerbit :
Universitas Indonesia, Jakarta, 1986.

Ronny Hanitijo Soemitro, Metodologi Penelitian Hukum dan Jurumetri, Ghalia Indonesia Jakarta, 1990.

Bambang Sunggono, Metode Penelitian Hukum, PT. Raja Grafindo Persada, Jakarta, 1997.

Lexie M. Giroth, "Status Pendidikan Pramong Praja Indonesia," CV. Indra Prahasta, 2004.

\section{Perundang-Undangan}

\section{UUD NRI 1945}

UU No. 23 Tahun 2014 tentang Pemerintahan Daerah.

UU No. 6 Tahun 2014 Tentang Desa

UU No. 43 Tahun 1999 Tentang Perubahan Atas UU No. 8 Tahun 1974 Tentang Pokok-Pokok Kepegawaian.

Peraturan Menteri Desa, Pembangunan Daerah Tertinggal, dan Transmigrasi Nomor 19 Tahun 2017.

Permendes Nomor 22 tahun 2016. 